\author{
PAWEE NoWAK \\ Uniwersytet Pedagogiczny w Krakowie, Polska \\ Pedagogical University of Cracow, Poland
}

\title{
Wpływ zmian systemowych i prawnych na poprawę adekwatności produktów ubezpieczeniowych do potrzeb i wymagań klientów
}

\section{The Impact of System and Legal Changes on Improving the Adequacy of Insurance Products to the Consumer's Needs and Requirements}

Streszczenie: Artykuł opisuje zmianę paradygmatu regulacyjno-nadzorczego oraz przepisów prawnych w aspekcie przeciwdziałania zjawisku nieuczciwej sprzedaży (ang. misseling) na rynku ubezpieczeniowym. Przedstawiono w nim istotę, formy oraz skalę występowania tego zjawiska. Dokonano analizy treści nowych regulacji prawnych, wprowadzonych w związku z transpozycją dyrektywy o dystrybucji ubezpieczeń IDD 2016/97 z 20 stycznia 2016 roku do polskiego porządku prawnego, z punktu widzenia możliwości ograniczenia nieuczciwej sprzedaży i nieadekwatności produktów ubezpieczeniowych do potrzeb i wymagań klientów. W szczególności przebadano przepisy dotyczące obowiązku działania w jak najlepiej pojętym interesie klienta, badania potrzeb i wymagań klientów oraz wynagradzania pośredników ubezpieczeniowych. Wnioski wskazują na głęboką zmianę modelu ochrony klienta na rynku ubezpieczeniowym. Implementacja przepisów dyrektywy IDD nie doprowadzi do ujednolicenia poziomu ochrony pomiędzy kanałami dystrybucji, natomiast wpłynie na ograniczenie konfliktu interesów i poprawi adekwatność produktów. Skuteczność przepisów będzie przede wszystkim zależała od zdolności do ich egzekwowania przez organy nadzoru. Artykuł powstał na podstawie studiów literatury przedmiotu oraz analizy treści przepisów prawnych.

\footnotetext{
Abstract: The article presents the changes in the supervisory paradigm and the latest legal regulation on insurance market aimed at prevention of misselling. First, the concept, form and scale of this phenomena were briefly described. There were analyzed some regulations of Insurance Distribution Directive (IDD) 2016/97 of 20 January 2016 implemented into Polish legal system, in aspect of their influence on reduction of misselling and inadequate sales to the needs of customers. In particular the norms imposing on distributors to act in the best interest of their consumers, necessity to recognize consumer's needs and expectations and the compensation system for agents were considered. The conclusions indicate fundamental reconstruction of consumer protection model on insurance market. The implementation of Insurance Distribution Directive will not cause the unification of consumer service between various channels of distribution but will reduce the conflict of interest between contract sides and the unsuitability of insurance products. The efficiency of regulations will depend on the ability of executions by supervisions authority first of all. Research methods used in the article include analysis of literature and legal regulations.
} 
Słowa kluczowe: dyrektywa o dystrybucji ubezpieczeń; nieuczciwa sprzedaż; ochrona konsumenta; ubezpieczenia

Keywords: consumer protection; insurance; insurance distribution directive; misselling

Otrzymano: 31 stycznia 2018

Receieved: 31 January 2018

Zaakceptowano: 20 maja 2018

Accepted: 20 May 2018

Sugerowana cytacja / Suggested citation:

Nowak, P. (2018). Wpływ zmian systemowych i prawnych na poprawę adekwatności produktów ubezpieczeniowych do potrzeb i wymagań klientów. Prace Komisji Geografii Przemysłu Polskiego Towarzystwa Geograficznego, 32(2), 164-174. https://doi.org/10.24917/20801653.322.11

\section{WSTĘP}

Współczesny rynek finansowy jest niestabilny i procykliczny, z tendencją do zachowań stadnych klientów usług finansowych (Małecki, 2014: 31; Monkiewicz, Monkiewicz, 2015: 7). Stało się to szczególnie widoczne w okresie kryzysu finansowego 2007-2010, gdy nadmierne ryzykowne działania instytucji finansowych najpierw zainicjowały, a następnie pogłębiały kryzys i omal nie doprowadziły do upadku światowej gospodarki. Mimo zapowiedzi ze strony władz publicznych, próby zapanowania państwa nad sektorem finansowym jak dotąd nie powiodły się. Instytucje finansowe (w tym ubezpieczeniowe) wciąż są źródłem ryzyka systemowego i poważnym zagrożeniem dla stabilności gospodarki, a relacje z nimi są przyczyną kłopotów konsumentów na masową skalę. Powszechny charakter nieprawidłowości w stosunkach konsumenckich stał się powodem włączenia ochrony konsumentów w zakres nadzoru makroostrożnościowego.

Problemy rynków finansowych spowodowane są m.in. nieuczciwą sprzedażą (ang. misselling), która polega na sprzedaży produktów nieużytecznych, zbędnych lub niekorzystnych dla klientów (zdarzają się również takie sytuacje, gdy klienci posiadają produkty finansowe i nawet o tym nie wiedzą) (Cichorska, 2017). Zmiany cywilizacyjne stworzyły warunki do rozwoju tego zjawiska. Nadmiar zadań i powszechne oczekiwanie, aby wszystko było zrealizowane natychmiast, powodują, że zainteresowanie sytuacją i potrzebami drugiej strony maleje. Konsumenci mają coraz więcej uprawnień, ale nie są w stanie z nich korzystać, ponieważ albo nie wiedzą o ich istnieniu, albo skorzystanie z nich byłoby psychicznie, czasowo lub ekonomicznie nieracjonalne (Więcko-Tułowiecka, 2014a: 51; Rutkowska-Tomaszewska, 2017: 101). Dlatego zmiany w modelu ochrony konsumenta na rynku finansowym stały się konieczne.

Artykuł koncentruje się na przedstawieniu zmian systemowych i przepisów prawnych, mających na celu przeciwdziałanie zjawisku nieuczciwej sprzedaży (nieadekwatności produktów ubezpieczeniowych do potrzeb i wymagań klientów). Celem artykułu jest analiza postanowień dyrektywy o dystrybucji ubezpieczeń IDD 2016/97 z 20 stycznia 1016 roku, wprowadzonej do polskiego porządku prawnego ustawą o dystrybucji ubezpieczeń z 15 grudnia 2017 roku (Dz.U. z 2017 r. poz. 2487), w kontekście ograniczenia zjawiska nieadekwatności produktów ubezpieczeniowych. W tym celu artykuł stara się odpowiedzieć na następujące pytania:

- jakie są istota i rozmiary nieuczciwej sprzedaży;

- w jakim kierunku ewoluuje model ochrony konsumenta na rynku ubezpieczeniowym; 
- w jaki sposób postanowienia dyrektywy IDD odnoszą się do zjawiska nieuczciwej sprzedaży;

- jakie są implikacje prawne i faktyczne wprowadzenia dyrektywy IDD dla poziomu ochrony konsumenta (klienta) na rynku ubezpieczeniowym.

Artykuł powstał na podstawie studiów literatury przedmiotu oraz analizy treści przepisów prawnych.

\section{PROBLEM NIEUCZCIWEJ SPRZEDAŻY}

Problem nieuczciwej sprzedaży polega na tym, że konsument kupuje produkt, który jest dla niego bezużyteczny, zbędny lub niekorzystny. Praktyki przedsiębiorców, naruszające interesy konsumentów i mieszczące się w pojęciu nieuczciwej sprzedaży, polegają na:

- oferowaniu konsumentom produktów finansowych, które nie odpowiadają ich potrzebom, szczególnie z uwzględnieniem wieku, stanu zdrowia, doświadczenia i wiedzy lub sytuacji materialnej,

- oferowaniu produktów finansowych w sposób nieadekwatny do ich charakteru.

Zaufanie klientów do instytucji sektora finansowego obniżył w ostatnich latach głównie rynek ubezpieczeń i kredytów hipotecznych denominowanych w walutach obcych. Pojawiło się na nim wiele nieprawidłowości. Ważniejsze z nich dotyczyły ubezpieczeń inwestycyjnych i miały postać nieuczciwej sprzedaży oraz wysokich opłat likwidacyjnych (Nowak, 2016). Rynek ubezpieczeniowy nie uchronił się także przed nieprawidłowościami w dystrybucji innych rodzajów ubezpieczeń, m.in. ubezpieczeń kredytów czy komunikacyjnych.

Kryzys finansowy lat 2007-2010 ujawnił powszechny charakter zjawiska nieuczciwej sprzedaży na rynku ubezpieczeniowym w krajach Europy Zachodniej (Więcko-Tułowiecka, 2014b). Stało się ono szczególnie głośne w Wielkiej Brytanii. Polegało na dodawaniu ubezpieczenia do kredytów bankowych (ang. Payment Protection Insurance, $P P I$ ). Ubezpieczenia miały chronić kredytobiorców (lub uposażonych) od ryzyka utraty zdolności spłaty rat kredytu, będącego następstwem zgonu, choroby bądź utraty pracy. W ciągu 10 lat na początku XXI wieku sprzedano w Wielkiej Brytanii ok. 34 mln takich polis - dwóch na trzech kredytobiorców posiadało taką polisę, choć połowa z nich w ogóle o tym nie wiedziała (Bielecki, Jasiński, Wiśnios, Wolińska, 2016).

Nieuczciwa sprzedaż w sektorze ubezpieczeniowym jest poważnym problemem również w Polsce. Według danych pochodzących z raportu Polskiej Izby Pośredników Ubezpieczeniowych i Finansowych z 2013 roku 20\% agentów ubezpieczeniowych oferuje klientom produkty, których albo nie chcą, albo nie potrzebują (Wierzbicka, 2016: 316). Problem ten dotyczy głównie agentów własnych zakładów ubezpieczeń, w mniejszym stopniu multiagentów, a największy jest w grupie agentów najmłodszych.

Nieuczciwa sprzedaż dotyczy głównie produktów finansowych, których stopień złożoności jest wysoki i dlatego niemożliwa jest ich ocena przez klienta. Do produktów finansowych najbardziej zagrożonych nieuczciwą sprzedażą zalicza się (Polityka..., 2015):

- ubezpieczenia na życie i dożycie z ubezpieczeniowym funduszem kapitałowym,

- kredyty hipoteczne denominowane w walutach obcych,

- kredyty konsumenckie na krótkie okresy,

- umowy zawierane pomiędzy nieobecnymi, poza lokalem lub na odległość. 
Jedną z głównych przyczyn nieuczciwej sprzedaży jest prowizyjny system wynagradzania pośredników finansowych, oparty na wynikach sprzedaży w krótkim okresie.

Współczesne produkty finansowe coraz częściej mają charakter międzysektorowy, o mieszanym charakterze. Podnosi to ich złożoność i utrudnia, a nawet uniemożliwia ocenę, zwłaszcza przez klientów bez specjalistycznej wiedzy. Pogłębia się w ten sposób zjawisko asymetrii informacyjnej i nierównowagi kontraktowej. Do produktów międzysektorowych, bardzo popularnych w Polsce, należą ubezpieczenia na życie z ubezpieczeniowym funduszem kapitałowym (UFK). Mają one zarówno cechy produktów inwestycyjnych, jak i ubezpieczeniowych. Należą do produktów strukturyzowanych, składających się z części ochronnej i inwestycyjnej. Ubezpieczenia na życie z UFK są popularne, ponieważ zapewniają ochronę kapitału (pełną lub częściową), umożliwią pełny lub częściowy wykup przed terminem wymagalności oraz dają możliwość wypracowania wyższego zysku.

Dystrybucja ubezpieczeń inwestycyjnych odbywa się poprzez różne kanały dystrybucji, wśród których ważną rolę odgrywają banki (bancassurance). Bardzo często oferują one ubezpieczenia w pakietach, w ramach sprzedaży łączonej - łącząc ich sprzedaż ze świadczeniem usług bankowych: prowadzeniem konta, kredytem hipotecznym lub konsumpcyjnym (Flejterski, Panasiuk, Perenc, Rosa, 2005).

Inwestycje w ubezpieczenia na życie z UFK obarczone są ryzykiem rynkowym, kredytowym i płynności, które obciąża klienta. Ryzyko rynkowe polega na tym, że w dniu wymagalności część inwestycyjna może być ujemna. Wtedy klient poniesie stratę i odbierze tylko część gwarantowaną. Ubezpieczający nie wie ex ante, jaki będzie miał dochód z inwestycji. Ryzyko kredytowe polega na tym, że zakład ubezpieczeń może upaść, a środki ulokowane w produkcie finansowym mogą nie być objęte gwarancją. Z kolei ryzyko płynności wiąże się z tym, że wycofanie środków przed terminem umowy jest niemożliwe lub nieopłacalne z uwagi na wysokie opłaty likwidacyjne. Klientów usług ubezpieczeniowych z UFK dotyka szczególnie ten rodzaj ryzyka.

\section{ZMIANY W PARADYGMACIE REGULACYJNO-NADZORCZYM NA RYNKU UBEZPIECZENIOWYM}

Do lat dziewięćdziesiątych XX wieku koncepcja ochrony konsumenta była oparta na założeniu, że dobrze poinformowany konsument jest zdolny do podejmowania racjonalnych decyzji. Opierała się raczej na wyborze konsumenta (ang. consumer choice), niż na prawach konsumenta (ang. consumer rights). Trybunał Sprawiedliwości UE przyznał, że orzecznictwo sądów unijnych w pierwszym okresie działania Wspólnoty nadało priorytet budowie wspólnego rynku, kosztem interesów konsumentów, którym stawiano zbyt wysokie wymogi co do wiedzy i uwagi przy podejmowaniu decyzji (Jurczyk, Majewska-Jurczyk, 2015: 462).

Stary paradygmat regulacyjno-nadzorczy ukształtował się w latach osiemdziesiątych XX wieku i wyrastał z doświadczeń neoliberalnej gospodarki, której symbolami stały się tacheryzm i reganomika. Opierał się na założeniu, że konsument jest zdolny do dokonywania świadomych wyborów, a ochronę konsumenta zapewnia konkurencja i informacja. W starym modelu ochronę konsumentom miała zapewnić przejrzystość rynku i ujawnianie informacji przez przedsiębiorców (zob. tab. 1). 
Tab. 1. Stary paradygmat regulacyjno-nadzorczy rynków finansowych

\begin{tabular}{|c|c|}
\hline Wymiary & Cechy \\
\hline Postrzeganie rynków finansowych & $\begin{array}{l}\text { - racjonalne, mądre i samonaprawiające się } \\
\text { - innowacje finansowe ważnym składnikiem stabilności finansowej } \\
\text { i bezpieczeństwa } \\
\text { - ład korporacyjny i model biznesu swobodnym wyborem } \\
\text { prywatnym }\end{array}$ \\
\hline Instrumentarium oddziaływania & $\begin{array}{l}\text { - dyscyplina rynkowa wspierana przez regulacje } \\
\text { - rozbudowana transparentność } \\
\text { - prywatny zarząd ryzkiem finansowym }\end{array}$ \\
\hline Charakter nadzoru & $\begin{array}{l}\text { - formalny i powierzchowny } \\
\text { - perspektywa mikroekonomiczna } \\
\text { - bezpieczeństwo domeną prywatną } \\
\text { - nadzór odizolowany od polityki }\end{array}$ \\
\hline
\end{tabular}

Źródło: Baker (2013), za Monkiewicz, Monkiewicz (2015: 7)

Skuteczność starego podejścia podważył światowy kryzys finansowy lat 20072010. Niską efektywność rozwiązań regulacyjnych opartych na starym paradygmacie regulacyjno-nadzorczym widać w rosnących obowiązkach informacyjnych nakładanych na przedsiębiorców z jednej strony i coraz większym zagubieniu i bezradności konsumentów z drugiej. Kryzys obnażył nieprawidłowości sektora finansowego i zanegował wiarę w zdolność rynku finansowego do samoregulacji. Podał również w wątpliwość umiejętności konsumentów w zakresie dokonywania właściwych wyborów. Stało się jasne, że współczesny konsument jest bezradny wobec złożonych produktów finansowych. Istnienie poważnych ograniczeń behawioralnych po stronie konsumentów, uniemożliwiających podejmowanie racjonalnych decyzji, znalazło powszechną akceptację. W ten sposób ochrona konsumenta nabrała nowego znaczenia i weszła w zakres nowego paradygmatu regulacyjno-nadzorczego.

Ów nowy paradygmat uchyla założenie o zdolności konsumenta do dokonywania racjonalnych wyborów i przyjmuje, że konsument nie jest w stanie podejmować racjonalnych decyzji na rynkach finansowych (zob. tab. 2). Konsekwencją tego założenia jest zwiększenie nadzoru regulacyjnego i przeniesienie na przedsiębiorców odpowiedzialności za nietrafne decyzje konsumenckie.

Tab. 2. Nowy paradygmat regulacyjno-nadzorczy rynków finansowych

\begin{tabular}{|c|c|}
\hline Wymiary & Cechy \\
\hline Postrzeganie rynków finansowych & $\begin{array}{l}\text { - procykliczne, często zawodne, bez gwarancji samonaprawy } \\
\text { - innowacje finansowe czynnikiem mogącym destabilizować system } \\
\text { finansowy } \\
\text { - ład korporacyjny i modele biznesu przedmiotem publicznej } \\
\text { kontroli }\end{array}$ \\
\hline Instrumentarium oddziaływania & $\begin{array}{l}\text { - dyscyplina regulacyjna wspierana przez rynkową } \\
\text { - rozbudowane uprawnienia nadzoru } \\
\text { - publiczny zarząd ryzykiem finansowym }\end{array}$ \\
\hline Charakter nadzoru & $\begin{array}{l}\text { - materialny i głęboki } \\
\text { - perspektywa makroostrożnościowa } \\
\text { - bezpieczeństwo domeną publiczną } \\
\text { - ochrona konsumentów ważnym elementem składowym systemu } \\
\text { nadzorczego } \\
\text { - nadzór infiltrowany przez politykę }\end{array}$ \\
\hline
\end{tabular}

Źródło: Baker (2013), za Monkiewicz, Monkiewicz (2015: 7) 
Nowy paradygmat regulacyjno-nadzorczy przewiduje daleko idącą ingerencję organów administracyjnych w formie tzw. interwencji produktowych na rynku ubezpieczeniowym, pozwalających regulatorowi wchodzić w ład korporacyjny i ingerować w charakter produktów finansowych, a w skrajnych przypadkach wycofać produkt z rynku na mocy decyzji administracyjnej (Monkiewicz, 2017). W ramach nowego podejścia instytucje finansowe muszą stworzyć wewnętrzne systemy nadzoru i zarządzania produktami finansowymi pod kątem badania ich adekwatności do potrzeb i interesów klientów. Celem wewnętrznego systemu przedsiębiorstwa staje się ciągła ewaluacja i walidacja produktów finansowych z punktu widzenia interesów konsumentów. Wszelkie działania z zakresu nadzoru i zarządzania produktami finansowymi powinny być udokumentowane i dostępne dla organów nadzorczych.

Jednym z założeń nowego podejścia jest rozszerzenie zakresu nadzoru na fazę przed wprowadzeniem produktu finansowego na rynek i skupienie na niej uwagi (nadzór wyprzedzający). Realizacja nadzoru wyprzedzającego realizowana jest m.in. poprzez narzucanie przez regulatora wymagań w zakresie zarządzania produktami finansowymi już na etapie ich projektowania. Cele i charakterystyki konsumentów powinny być należycie uwzględnione w projektowaniu i wprowadzaniu produktów ze wskazaniem klientów, dla których dany produkt jest odpowiedni, i tych kategorii klientów, którym produkt nie powinien być oferowany. Zakłady ubezpieczeń powinny wprowadzać na rynek tylko te produkty, których cechy, ceny, ryzyka i kanały dystrybucji odpowiadają interesom rynków docelowych.

Przy ocenie adekwatności produktu instytucje finansowe muszą brać pod uwagę poziom wiedzy i doświadczenie klienta, jego wiek, stan zdrowia i status materialny. Nowe podejście obejmuje również obowiązek testowania produktów przed wprowadzeniem ich na rynek i przeprowadzanie analiz scenariuszowych. Instytucje finansowe powinny dokonywać przeglądu wprowadzonego systemu i wprowadzać w nim zmiany, jeżeli to będzie konieczne.

Pewne obowiązki, dotychczas tylko o charakterze prywatnoprawnym, stały się obowiązkami o charakterze publicznoprawnym (Szaraniec, 2017a). Publicznoprawny charakter obowiązków polega na tym, że do ich egzekwowania powołane są organy nadzoru, a ich niewykonanie zagrożone jest sankcją administracyjną. Nowy ład regulacyjno-nadzorczy wskazuje na dominację regulacji z zakresu prawa publicznego nad regulacjami z zakresu prawa prywatnego w tym przedmiocie. Normy publicznego prawa gospodarczego zaczynają bezpośrednio wpływać na produkty ubezpieczeniowe na rynku ubezpieczeń gospodarczych - m.in. poprzez nadawanie działaniom informacyjnym instytucji finansowych charakteru publicznoprawnego, a nie tylko prywatnoprawnego.

\section{ZMIANY PRAWNE OGRANICZAJĄCE ZJAWISKO NIEUCZCIWEJ SPRZEDAŻY}

10 października 2018 roku wchodzi w życie ustawa o dystrybucji ubezpieczeń, która wprowadza do krajowego porządku prawnego przepisy unijnej dyrektywy IDD (Insurance Distribution Directive) 2016/97 z 20 stycznia 2016 roku w sprawie dystrybucji ubezpieczeń. Jest to jeden z ważniejszych aktów prawnych, który wprowadza wiele zmian i znacząco wpłynie na rynek pośrednictwa ubezpieczeniowego. Jednym z podstawowych celów dyrektywy jest podniesienie poziomu ochrony klientów zawierających umowę ubezpieczenia, który realizowany jest m.in. poprzez zapewnienie odpowiedniej informacji o produkcie oraz dystrybutorze ubezpieczenia. Ustawa zakłada, że 
klienci będą korzystać z jednakowej ochrony, niezależnie od kanału dystrybucji. Ogólnym celem dyrektywy jest harmonizacja krajowych rynków ubezpieczeń w zakresie bezpośredniego i pośredniego świadczenia usług ubezpieczeniowych na wewnętrznym rynku finansowym UE oraz ochrona klientów tych usług w aspekcie ich skomplikowanej struktury i nieprawidłowości pojawiających się na tym rynku.

Dyrektywa IDD zobowiązuje dystrybutorów ubezpieczeń do „uczciwego, rzetelnego i profesjonalnego postępowania, zgodnie z najlepiej pojętym interesem klientów" (art. 17 ust. 1). W myśl dyrektywy dystrybutorami ubezpieczeń są zakład ubezpieczeń, agent ubezpieczeniowy, agent oferujący ubezpieczenie uzupełniające oraz broker ubezpieczeniowy. Wszystkie informacje marketingowe kierowane przez dystrybutora ubezpieczeń do klientów lub potencjalnych klientów powinny być rzetelne, jasne i niewprowadzające w błąd.

Obowiązek działania w jak najlepiej pojętym interesie klienta - mający zapewnić adekwatność produktów ubezpieczeniowych - dotyczy wszystkich rodzajów ubezpieczeń i wszystkich dystrybutorów. Różnice w realizacji tego przepisu będą występować w zależności od rodzaju produktu ubezpieczeniowego i rodzaju pośrednika. Działanie w jak najlepiej pojętym interesie klienta w przypadku agentów będzie miało podobny zakres jak zakładów ubezpieczeń, natomiast będzie węższe niż w przypadku brokerów. Realizacja tego obowiązku przez agenta będzie polegała na udzielaniu obiektywnych informacji o produktach i ostrzeżeń odnośnie do ryzyka. Nie jest rolą agentów udzielanie rad czy namawianie do wyboru któregoś wariantu. Na brak takich obowiązków wskazuje m.in. brak wymagań ustawowych co do przygotowania zawodowego agenta.

Natomiast działanie brokerów, poza informowaniem i ostrzeganiem, czyli tym, co uniwersalne $\mathrm{w}$ obowiązkach informacyjnych pośrednika, będzie polegało dodatkowo na udzielaniu indywidualnych rekomendacji odnośnie do umowy ubezpieczenia, która w najwłaściwszy sposób spełni oczekiwania klienta, przedstawianiu pisemnych opinii mających na celu optymalizację decyzji klienta. Wykonanie obowiązków informacyjnych przez agentów wyłącznych, oferujących produkty tylko jednego ubezpieczyciela, będzie łatwiejsze aniżeli multiagentów, mających w swojej ofercie produkty kilku ubezpieczycieli. Niejednolite zasady konstruowania produktów ubezpieczeniowych powodują, że ocena i porównanie tych produktów nie jest łatwe.

Wpływ na stopień adekwatności produktów ubezpieczeniowych ma sposób wynagradzania pośredników. Istnieje niebezpieczeństwo, że pośrednik zależny (agent wyłączny lub multiagent), który jest wynagradzany przez zakład ubezpieczeń w niedostatecznym stopniu, będzie działał w interesie klienta, kierując się przede wszystkim interesem instytucji, od której otrzymuje wynagrodzenie. Zgodnie z art. $758^{1}$ k.c. zasadą przy wynagrodzeniu agenta jest system prowizyjny. Agent na podstawie umowy agencyjnej zawartej z mocodawcą zobowiązany jest do działania w interesie i na rzecz mocodawcy. Zobowiązuje go do tego wymóg obustronnej lojalności stron umowy agencyjnej wynikający z art. 760 k.c. (Orlicki, 2017: 23).

Wynagrodzenie brokera nie jest uregulowane prawnie. Formą dominującą, ukształtowaną przez zwyczaj, jest wynagrodzenie prowizyjne (kurtaż) wypłacane przez ubezpieczyciela. Ponieważ broker działa $w$ interesie i na rzecz podmiotu poszukującego ochrony ubezpieczeniowej i ubezpieczyciela, najbardziej właściwe byłoby wynagrodzenie płacone przez te podmioty. W praktyce jednak bardzo rzadko broker otrzymuje wynagrodzenie od zleceniodawcy. Zdarza się to tylko w przypadku dużych zleceniodawców, gdy obowiązki brokerskie są szerokie i obejmują zarządzanie ryzykiem, 
doradztwo, pomoc w likwidacji szkody czy opracowanie programu ubezpieczeniowego (Malinowska, 2012: 153). Broker ubezpieczeniowy nie może pozostawać w jakimkolwiek stałym stosunku umownym z zakładem ubezpieczeń, zakładem reasekuracji, agentem ubezpieczeniowym lub agentem oferującym ubezpieczenia uzupełniające. W praktyce stosowane są często umowy o współpracy o charakterze kompleksowym (Szaraniec, 2017b: 193). Nie mogą one jednak wkraczać w sferę współpracy tak dalece, aby naruszały wskazany zakaz ustawowy lub prowadziły do konfliktu interesów.

Działanie w jak najlepiej pojętym interesie klientów ma zapewnić zakaz wynagradzania dystrybutorów ubezpieczeń (w tym zakaz wynagradzania pracowników) i oceny ich wyników w sposób sprzeczny z obowiązkiem działania w jak najlepiej pojętym interesie klientów. W art. 29 IDD przyjmuje się, że najlepiej pojęty interes klienta uznaje się za zachowany w przypadku, gdy pośrednik ubezpieczeniowy otrzymuje jakiekolwiek korzyści pieniężne i niepieniężne w związku z dystrybucją ubezpieczeniowego produktu inwestycyjnego, za wyjątkiem klienta lub osoby występującej w jego imieniu, wyłącznie w przypadku, gdy opłata lub korzyść:

a) nie wywiera szkodliwego wpływu na jakość odnośnej usługi świadczonej na rzecz klienta oraz

b) nie narusza spoczywającego na dystrybutorze ubezpieczeń obowiązku uczciwego, rzetelnego i profesjonalnego działania zgodnie z najlepiej pojętym interesem klienta.

Pojawia się w związku z tym pytanie, na jakiej podstawie oceniać, czy działanie jest zgodne z najlepiej pojętym interesem klienta. W tym zakresie Komisja Europejska na podstawie art. 29 ust. 4 IDD została uprawniona do przyjęcia aktów precyzujących kryteria oceny, czy zachęty wypłacane lub otrzymane przez pośrednika ubezpieczeniowego bądź zakład ubezpieczeń wywierają szkodliwy wpływ na jakość usługi, oraz kryteria wywiązywania się pośredników i zakłady ubezpieczeń z obowiązku uczciwego, rzetelnego i profesjonalnego działania zgodnie z najlepiej pojętym interesem klienta. W odpowiedzi na wniosek Komisji Europejskiej Europejski Urząd Nadzoru Ubezpieczeń i Pracowniczych Programów Emerytalnych (European Insurance and Occupational Pensions Authority, EIOPA) przygotował poradę techniczną, w ramach której odniósł się m.in. do zachęt wskazanych w art. 29 ust. 2 IDD.

EIOPA wskazał, że zachęta lub system zachęt ma szkodliwy wpływ na jakość usług, jeżeli ma charakter i skalę, która stanowi motywację do wykonywania działalności dystrybucyjnej w sposób niezgodny z najlepiej pojętym interesem klienta. W celu stworzenia kryteriów ewaluacyjnych EIOPA przygotował przykładową listę konstrukcji zachęt, które mogą zostać uznane za szkodliwe dla jakości usług. Na liście znalazły się następujące praktyki (Tarasiuk, 2017: 127-128):

- zachęta lub system zachęt stanowi motywację do oferowania lub rekomendowania konkretnego produktu ubezpieczeniowego, mimo że istnieją w ofercie pośrednika inne produkty lepiej odpowiadające potrzebom klientów;

- zachęta lub system zachęt opiera się wyłącznie lub w przeważającym stopniu na kryteriach ilościowych, bez uwzględnienia odpowiednich kryteriów jakościowych opartych na jakości usług i zadowoleniu klienta;

- wartość zachęty jest nieadekwatna (zbyt wysoka) w stosunku do wartości oferowanego produktu ubezpieczeniowego; 
- zachęta jest w całości lub w znacznej części wypłacana z góry, bez mechanizmu odzyskania jej w całości lub części w wypadku, gdy umowa ubezpieczenia przedwcześnie uległa zakończeniu;

- istnieje mechanizm, który wiąże wysokość zachęty z osiągnięciem określonych progów opartych na wielkości lub wartości sprzedaży.

Prawidłowy system wynagradzania pośrednika przez zakład ubezpieczeń powinien opierać się głównie na kryteriach jakościowych i dawać możliwość zwrotu zachęty ubezpieczycielowi w przypadku naruszenia interesów klienta w trakcie wykonywania usług pośrednictwa.

Jednocześnie EIOPA wskazał, że podana lista nie jest katalogiem zamkniętym i niewystępowanie żadnego z powyższych przykładów u dystrybutora nie stanowi o zgodności z przepisami prawa i celami dyrektywy. Podobnie wystąpienie któregoś z przykładów nie może być podstawą do oceny negatywnej. Wymagane jest całościowe spojrzenie i kompleksowa ocena przez dystrybutora. Podstawowym obowiązkiem każdego dystrybutora pozostaje więc ustalenie, czy dana zachęta nie wpływa w sposób szkodliwy na adekwatność produktu i czy zastosowane rozwiązania są wystarczające do ograniczenia ryzyka takiego szkodliwego wpływu, biorąc pod uwagę indywidualne okoliczności danej sprawy.

EIOPA zaznacza, że system zachęt powinien być ustalony przy uwzględnieniu powyższych rekomendacji i zatwierdzony przez organy zarządzające dystrybutora, a wyniki analizy powinny być udokumentowane na trwałym nośniku.

W dyrektywie uregulowano m.in. kwestię ujawniania przez dystrybutorów ubezpieczeń charakteru ich wynagrodzenia. Dystrybutor ubezpieczeń będzie musiał ujawnić, czy za swoją pracę otrzymuje honorarium (płacone bezpośrednio przez klienta), prowizję (uwzględnioną w kwocie składki ubezpieczeniowej), czy jakiś inny rodzaj wynagrodzenia. W przypadku umów ubezpieczenia na życie o charakterze inwestycyjnym zobowiązano też agentów ubezpieczeniowych, zakłady ubezpieczeń i brokerów ubezpieczeniowych do informowania klientów o wysokości wskaźnika kosztów dystrybucji oraz wskaźnika kosztów prowizji, związanych z proponowaną umową ubezpieczenia.

Wpływ ujawniania informacji o wysokości wynagrodzeń na optymalizację decyzji i lepsze dopasowanie produktów do potrzeb konsumentów budzi wątpliwości. Polegają one na tym, że to nie merytoryczna ocena warunków ubezpieczenia, ale wysokość prowizji znajdzie się w centrum uwagi klienta i stanie się główną podstawą oceny oferty. Jak wskazują niektóre badania, wprowadzenie jawności wynagrodzeń pośredników nie poprawia racjonalności decyzji - konsumenci bywają skłonni przywiązywać nadmierną uwagę do wynagrodzenia pośredników, zapominając o koszcie samej usługi (Lacko, Pappalardo, 2004). Informacja na temat wysokości wynagrodzenia może wpływać zniechęcająco na przekonanie o celowości zakupu ochrony ubezpieczeniowej (Szaraniec, 2013). Ponadto konsumenci mogą próbować unikać płacenia prowizji, zwracając się bezpośrednio do ubezpieczycieli, pozbawiając się samowolnie możliwości wyboru, nie zdając sobie sprawy, że ceny w różnych kanałach dystrybucji są jednakowe.

Dyrektywa stanowi niezbędne ujednolicenie zasad ochrony konsumenta na rynkach inwestycyjnych, wynikającej z MiFID I i MiFID II, i na rynku ubezpieczeniowym (Michór, 2015). Wcześniej, mimo iż ubezpieczenia na życie z UFK są zbliżone do produktów inwestycyjnych, klienci byli pozbawieni takiej ochrony. 


\section{ZAKOŃCZENIE}

Na rynku finansowym ma miejsce głęboka zmiana paradygmatu regulacyjno-nadzorczego. Wszystko po to, aby rynek ten stał się bardziej przejrzysty, uporządkowany, zrozumiały i bezpieczny dla klienta. Wdrożenie przepisów dyrektywy IDD podniesie poziom ochrony klienta na rynku ubezpieczeniowym. Wprowadza ona podobne zasady ochrony na rynku ubezpieczeń inwestycyjnych, jak już obowiązujące zasady na rynkach innych produktów inwestycyjnych, wynikające z wcześniejszego wdrożenia dyrektyw MiFID I i MiFID II. Jej postanowienia regulują kwestie wynagrodzeń (zachęt) pośredników i pracowników sprzedaży, które były powszechnie źródłem konfliktu interesów podmiotów stosunku ubezpieczeniowego.

Dyrektywa IDD nakłada na wszystkich dystrybutorów obowiązek działania w jak najlepiej pojętym interesie klienta. Pełne ujednolicenie poziomu ochrony, będące przesłanką wprowadzenia dyrektywy, pomiędzy kanałami dystrybucji nie będzie jednak możliwe. Wynika to z ustawowego zróżnicowania obowiązków agenta i brokera. Realizacja obowiązku działania $\mathrm{w}$ jak najlepiej pojętym interesie klienta przez agenta czy pracownika zakładu ubezpieczeń będzie miała węższy charakter, aniżeli brokera. Klienci poszukujący doradztwa ubezpieczeniowego powinni skorzystać z usług brokera, a ci, którzy mają jeszcze wyższe oczekiwania, z doradcy inwestycyjnego. Stopień realizacji postanowień dyrektywy będzie zależał od zdolności do wyegzekwowania jej postanowień przez organy nadzoru.

\section{Literatura \\ References}

Baker, A. (2013). The New Political Economy of the Macroprudential Ideational Shift. New Political Economy, 18(1), 112-139.

Bielecki, M., Jasiński, A., Wiśnios, Z., Wolińska, B. (2016). Ubezpieczenie sprzętu elektronicznego. Raport rzecznika finansowego. Warszawa: Rzecznik Finansowy.

Cichorska, J. (2017). Misselling, czyli sprzedaż niepotrzebnych instrumentów finansowych i jej skutki. Stan prawny w Polsce i Wielkiej Brytanii. Journal of Insurance, Financial Markets \& Consumer Protection, 24(2), 18-34.

Flejterski, S., Panasiuk., A., Perenc, J., Rosa, G. (red.) (2005). Współczesna ekonomika usług. Warszawa: Wydawnictwo Naukowe PWN.

Jurczyk, Z., Majewska-Jurczyk, B. (2015). Model ochrony konsumentów w Unii Europejskiej. Prace Naukowe Uniwersytetu Ekonomicznego we Wrocławiu, 380, 453-464.

Lacko, J.M., Pappalardo, J.K. (2004). The Effect of Mortgage Broker Compensation Disclosures on Consumers and Competition: A Controlled Experiment. Washington: Federal Trade Commission.

Malinowska, K. (2012). Broker a ubezpieczyciel. W: M. Serwach (red.). Broker w świetle prawa i praktyki ubezpieczeniowej. Łódź: Wydawnictwo Uniwersytetu Łódzkiego.

Małecki, W. (2014). Przeciwdziałanie procykliczności sektora bankowego. Gospodarka Narodowa, $4(272), 27-54$.

Michór, A. (2015). Ubezpieczenia na życie z ubezpieczeniowym funduszem kapitałowym a ochrona konsumenta. Bezpieczny Bank, 1(58), 156-182.

Monkiewicz, J. (2017). W poszukiwaniu nowego paradygmatu ochrony konsumentów na rynkach finansowych. Jak chronić konsumenta na rynku finansowym? Modele i doświadczenia międzynarodowe. Materiały konferencyjne. Warszawa: Rzecznik Finansowy.

Monkiewicz, J., Monkiewicz, M. (2015). Tendencje rozwoju ochrony konsumentów na rynku ubezpieczeniowym. Rozprawy Ubezpieczeniowe, 18(1), 5-17. 
Nowak, P. (2016). Bezpieczeństwo ekonomiczne konsumenta na rynkach usług finansowych. W: A. Piędel, J. Pomiankiewicz, A. Żebrowski (red.). Współczesne aspekty bezpieczeństwa państwa. Nisko: Wyższa Szkoła Bezpieczeństwa i Ochrony im. Marszałka Józefa Piłsudzkiego w Warszawie, Wydział Zamiejscowy w Nisku.

Orlicki, J. (2017). Aksjologia dystrybucji ubezpieczeń - kryteria uznawania działań dystrybutora za zgodne z prawem i etyczne. W: B. Gnela, M. Szaraniec (red.). Dystrybucja usług ubezpieczeniowych. Wybrane zagadnienia prawne. Warszawa: Difin.

Polityka ochrony konkurencji i konsumentów (2015). Warszawa: Urząd Ochrony Konkurencji i Konsumentów.

Rutkowska-Tomaszewska, E. (2017). Zakres podmiotowy ochrony klienta i jej mechanizmy na regulacji dotyczących dystrybucji ubezpieczeń. W: B. Gnela, M. Szaraniec (red.). Dystrybucja usług ubezpieczeniowych. Wybrane zagadnienia prawne. Warszawa: Difin.

Szaraniec, M. (2013). Kontrowersje wokół relacji łączącej brokera z ubezpieczycielem w zakresie wynagrodzenia brokera w świetle projektu zmiany dyrektywy2002/92 WE o pośrednictwie ubezpieczeniowym. W: J. Kruczalak-Janowska (red.). Wpływ europeizacji prawa na instytucje prawa handlowego. Warszawa: LexisNexis.

Szaraniec, M. (2017a). Publicyzacja regulacji dystrybucji usług ubezpieczeniowych. W: B. Gnela, M. Szaraniec (red.). Dystrybucja usług ubezpieczeniowych. Wybrane zagadnienia prawne. Warszawa: Difin.

Szaraniec, M. (2017b). Działalność gospodarcza pośredników ubezpieczeniowych. Studium publicznoprawne. Warszawa: Difin.

Tarasiuk, A. (2017). Zachęty do rekomendowania klientom konkretnego produktu ubezpieczeniowego na tle dyrektywy IDD oraz wytycznych EIOPA. W: B. Gnela, M. Szaraniec (red.). Dystrybucja usług ubezpieczeniowych. Wybrane zagadnienia prawne. Warszawa: Difin.

Wierzbicka, E. (2016). Misseling barierą rozwoju ubezpieczeń w Polsce. Zeszyty Nakowe Wyższej Szkoły Humanistycznej. Zarządzanie, 2, 315-327.

Więcko-Tułowiecka, M. (2014a). Ochrona konsumentów w umowach ubezpieczenia. Warszawa: LexisNexis.

Więcko-Tułowiecka, M. (2014b). Ubezpieczenia kredytu w wybranych pastwach Unii Europejskiej w ocenie Europejskiego Urzędu Nadzoru Ubezpieczeń. Rozprawy Ubezpieczeniowe, 17(2), 144-158.

Wojewoda-Leśniewicz, K. (2017, 15 grudnia). Przełomowy wyrok sqqdu: polisolokaty niewiarygodnie oszukańcze. Pozyskano z http://www.bankier.pl/wiadomosc/Przelomowy-wyroksadu-polisolokaty-niewiarygodnie-oszukancze-7270243.html

Paweł Nowak, dr, ekonomista, adiunkt w Katedrze Ekonomii i Polityki Gospodarczej Uniwersytetu Pedagogicznego w Krakowie. Zainteresowania naukowe: mikro- i makroekonomia, bezpieczeństwo obrotu gospodarczego i ochrona konsumenta. Autor publikacji naukowych z zakresu ekonomii, prawa i finansów.

Paweł Nowak, Ph.D., economist and assistant professor in the Department of Economics and Economic Policy, the Pedagogical University of Cracow. Main research interests: economy, safety of transaction and consumer protection. He is the author of numerous articles on economics, law and finance.

\section{Adres/address:}

Uniwersytet Pedagogiczny w Krakowie,

Katedra Ekonomii i Polityki Gospodarczej

ul. Podchorążych 2, 30-084 Kraków, Polska

e-mail: gelb@wp.pl 